\title{
KALKITUKSEN VAIKUTUKSISTA MAAPERÄN ORGAANISEEN JA HELPPOLIUKOISEEN FOSFORIIN.
}

\author{
Martti Salonen. \\ Yliopiston maanviljelyskemian laitos, Helsinki. \\ Saapunut 14. II. 1946.
}

Kauan tunnettu tosiasia on, että kalkitus usein lisää maan fosforin tulemista kasvien käyttöön. Tämä on todettu lukuisissa kenttä- ja astiakokeissa sekä kasvinviljelyksessä. Myös uuttamismenetelmillä voidaan todeta kalkituksen maan helppoliukoista fosforia lisäävä vaikutus. On pantu merkille, että kalkitus lisää maaperän fosforin käyttökelpoiseksi muuttumista eniten kaikkein happamimmissa ja eniten kalkitusta kaipaavissa maissa. Etenkin viime vuosina, kun fosfaattilannoiłteista on ollut suuri puute, on myös meillä kiinnitetty paljon huomiota mainittuun ilmiöön.

Maassa on fosforia useassa eri muodossa. Se voidaan jakaa ryhmiin esim. seuraavasti $(6)$ :

I. Epäorgaanisina yhdistyksinä oleva fosfori.

1. Mineraalifosfaatit.

2. Pidättyneenä olevat fosfaatit, jotka Mattsovin mukaan voidaan jaoitella misellaarisesti (kolloidisesti ja saloidisesti) ja ekstramisellaarisesti sidottuun fosfaattiin.

II. Orgaanisina yhdistyksinä oleva fosfori.

Kasvien ravinnonotossa eivät mineraalifosfaatit vaikealiukoisuutensa vuoksi juuri tule kysymykseen. Lisäksi suuri osa niistä on etenkin karkearakeisessa maassa maahiukkasten sisässä.

Pidättyneenä oleva fosfori on lähinnä kasvien käytettävissä. Tunnettua on kuitenkin, ettei sekään tavallisesti ole helposti ja suuressa määrässä kasvien saatavissa. Kalkituksen vaikutuksen yhteydessä on eniten kiinnitetty huomiota siihen, että happamissa maissa pääasiassa esiintyvät ferri- ja aluminiumfosfaatit, tai oikeammin ferri- ja aluminiumhydroksideihin pidättyneet fosfaatti-ionit (4), hydrolysoituvat, kun reaktiota nostetaan (3), jolloin fosfaatti tulee liuokseen. Useissa yhteyksissä on kiinnitetty huomiota myös siihen, että erilaisten negatiivisten kolloidien (humus, piihappo) vaikutuksesta fosfaatti pysyy paremmin liuoksessa, vaikka 
maassa onkin paljon fosfaattia vahvasti pidättäviä positiivisia kolloideja, ferri- ja aluminiumhydroksideja. Tämänkin ilmiön merkitystä kasvien fosfaattien saannissa on paljon tutkittu (hyvän katsauksen näihin tutkimuksiin on laatinut SEMB (8), mutta tulokset ovat toistaiseksi epäselvät (9).

Orgaaninen fosfori muodostaa suuren ja epämääräisen ryhmän, jonka merkitys kasvien fosforin saannissa on vaillinaisesti tunnettu. Selvää on kuitenkin, että orgaanisen aineen hajaantuessa vapautuva fosfaatti on helposti kasvien käytettävissä. Kalkituksen vaikutuksesta maan orgaanisen fosforin määriin en ole käytettävissäni olevasta kirjallisuudesta löytänyt mitään tutkimuksia enempää kuin arvelujakaan. Yleinen käsitys näyttää olevan, että kalkituksen liukoista fosforihappoa lisäävä vaikutus johtuu sen ferri- ja aluminiumfosfaatteja hydrolysoivasta ominaisuudesta. Kun orgaanisen fosforin määrä maassa yleensä on huomattavan suuri, ja juuri nimenomaan maissa, joissa kasvien fosforin saanti on erityisen vaikeaa, olisi sen liukenemisedellytyksien tuntemisella suuri merkitys.

\section{Fosforin mobilisoituminen erilaisista maista.}

Saadakseni tietoja siitä, miten orgaanisen fosforin määrä muuttuu maanäytteissä, joita säilytetään kostutettuina, kalkittuina ja ilman kalkkia huoneen lämmössä, tein mobilisoitumiskokeen erilaisilla maanäytteillä.

Kokeessa käytetyistä maanäytteistä ovat u r pas a vi 3 ja 4, a i t o s a vi 5 ja 6 sekă hie tas a vi 7 otetut samalla kertaa kuin eräăssä aikaisemmassa tutkimuksessani (6) käytetyt, samoilla merkinnöillä varustetut näytteet, mutta ne on homogenisoitu eri kerralla, joten niiden ominaisuuksissa on pieniä eroja verrattuna aikaisemmin esitettyihin lukuihin, mutta niitä voitaneen kuitenkin pităä samoina näytteinä.

Muut tässä käytety maanäytteet on otettu kesällä 1939, mutta niitä ei ole voitu aikaisemmin tutkia. Ne on otettu eri lannoituskoekentistä. V a k kila A, B ja C on otettu Etelä-Pohjanmaan koeasemalla Ylistarossa v. 1931 aloitetusta kokeesta, jossa vertaillaan erilaisen lannoituksen jatkuvan käytön vaikutuksia. Tutkimuksessa on käytetty ruuduilta $A_{1}, B_{1}$ ja $C_{1}$ otettuja näytteită. Mainitut ruudut ovat rinnakkain, ja maa on niillä ilmeisesti samanlaatuista, Etelä-Pohjanmaan jokivarsilla esiintyvää kevyttä savea.

Maanäytteet Ko ke mä k i 0 ja K o k e mä k i 2 PN on otettu Satakunnan koeasemalla Kokemäellä v:sta 1930 alkaen käynnissä olleesta pitkäaikaisesta lannoituskokeesta. Näyte 0 on yhdistetty ruuduilta 1, 11 ja 21 ja näyte 2 PN ruuduilta 4 ja 14 otetuista näytteistä. Maalaji on hiekansekaista hietaa.

Merkinnällä Myttäälä varustetut maanäytteet on otettu Pohjois-Hämeen koeasemalla Pälkäneellä v:sta 1930 käynnissä olleesta suuresta nousevien typpi- ja fosfaat timäärien kokeesta. Maa on melko karkeata hiekkaa.

Tiedot eri koeruutujen lannoituksesta on esitetty taulukossa 1. Lannoituskoekenttien eri ruuduilta otetut näytteet on yhdistetty 20:stä koko kyntömultakerroksen läpi menevästä kairauksesta.

Mobilisaatiokoe tehtiin siten, että $100 \mathrm{~g}$ :an maanäytteen kuiva-ainetta sekoitettiin kalkki, analyysipuhdas $\mathrm{CaCO}_{3}$, maa kostutettiin sopivasti ja pantiin pulloon, joka suljettiin höllällä paperitukolla haihtumisen vähentämiseksi. Käytetyt $\mathrm{CaCO}_{3}$-määrät nähdään taulukosta 1. Kerran kuukaudessa korvattiin haihtunut vesi ja maa sekoitettiin. Pullot säilytettiin laboratorion kaapissa. Koekauden aikana laboratorion lämpötila oli 4 ensimmäistä kuukautta $14-17^{\circ}$, sen jälkeen 
3 kuukautta $20-21^{\circ}$ ja 2 viimeistä kuukautta $15-18^{\circ}$. 9 kuukauden kuluttua koe lopetettiin, jolloin maanäytteet kuivattiin ja homogenisoitiin.

Maanäytteistä mitattiin koekauden jälkeen $\mathrm{pH}$ ja tehtiin uutokset laktaattiliuoksella (2), jolloin käytettiin uutossuhdetta $2 \mathrm{~g}$ maata: $200 \mathrm{ml}$ uutosnestettä, jotta kalkituista näytteistä tehtyjen uutteiden $\mathrm{pH}$ pysyisi säädetyissä rajoissa. Uutteiden $\mathrm{pH}$ todettiin mittauksilla. Orgaanisen fosforin määrä selvitettiin käyttäen $0.25 \mathrm{n}$. NaOH (6). Lisäksi tehtiin muutamısta näytteistä humusmääritykset dikromaattihapetuksella (1). Eri määritysten tulokset esitetään taulukossa 1, johon on laskettu myös eri fosforifraktioiden määrät prosentteina totalifosforista. Eri fosforiluvut on otettu taulukkoon sellaisinaan, tekemättä niihin korjauksia lısätyn kalkkimäärän vuoksi, sillä tästä syystä tehtävä korjaus olisi joka tapauksessa pieni, enint. $2 \%$, ja on syytä arvioida analyysivirheet suuremmiksi.

Taulukon 1 orgaanisen fosforin lukuja tarkasteltaessa huomataan ensiksikin, että sen määrät eri maissa vaihtelevat jonkin verran. Eniten, lähes puolet koko fosforista, sitä on urpasavessa 3. Hiekkanäytteissä on orgaanista fosforia runsas kolmannes koko fosforista, aitosavi 5:ssä, Kokemäen hiedassa ja Ylistaron kevyessä savessa n. $40 \%$. Vähiten orgaanista fosforia on pohjamaanäytteissä ja niistä erityisesti aitosavi 6:ssa, mikä onkin luonnollista, kun maassa ei ole juuri nimeksikään orgaanista ainetta. Epäorgaanista emäkseen liukenevaa fosforia (= ferri- ja aluminiumfosfaatteja) on yleensä vähemmän kuin orgaanista, poikkeuksena kuitenkin pohjamaanäytteet ja Myttäälän hiekka.

Koekentiltä otetuista näytteistä saatujen lukujen mukaan näyttää siltä, että lannoitus on lisännyt orgaanisen fosforin määrää samassa suhteessa kuin totalifosforiakin, sillä orgaanisen fosforin prosenttimäärissä ei ole havaittavissa mitään selviä eroja. Näyttää siltä, että orgaanisen samoin kuin maan koko emäkseen liukenevan fosforin määrä riippuu enemmän maalajista kuin lannoituksesta.

Tarkasteltaessa kalkituksen vaikutusta orgaanisen fosforin määriin huomataan, että kalkitus yleensä on sitä vähentänyt, joskin vähennys on melko pieni. Selvin ja prosenttisesti suurin kalkituksen aiheuttama orgaanisen fosforin väheneminen on hiekka- ja hietanäytteissä, joissa kaikki ilmiöt ja erityisesti pieneliöiden aiheuttamat tapahtuvat nopeammin kuin savissa. Huomattavan suuri on väheneminen myös aitosavi 5:ssä, joka on erittäin hyvää viljelysmaata. Aivan mitätön tämä väheneminen on pohjamaanäytteissä urpasavi 4 ja aitosavi 6 . Näistä on tosin sanottava, että orgaanisen fosforin määricys niistä on hyvin epävarmaa, kun sen määrät ovat niin pienet ja määritystavasta johtuen virheet tässä ovat suuret. Kun orgaaninen fosfori lasketaan erotuksena kahdesta eri määrityksestä, kasaantuvat molempien virheet tähän erotukseen.

Mihin muotoon sitten muuttuu fosfori, joka vapautuu orgaanisesta aineesta? Tähän antavat valaistusta emäkseen liukenevan epäorgaanisen fosforin ja laktaattiuutoksella saatavan fosforin määrät. Emäkseen liukenevan epäorgaanisen fosforin määrät ovat kalkituksen johdosta muuttuneet sangen vähän, lukuunottamatta pohjamaanäytteitä, joissa sen väheneminen on selvää. Jos siis kalkitus vaikuttaa epäorgaaniseen emäkseen liukenevaan fosforiin, niin se vähentää sitäkin. Sensijaan on laktaattiin liukeneva fosfori kalkituksen johdosta lisääntynyt selvästi, useissa 
Taulukko I. Kalkituksen vaikutus evi tavalla liukenevaan fosforiin, luvut mg $P / k g$ maata

Table 1. The effect of liming on phophorus soluble in different ways. Figures express phosphorus in $\mathrm{mg}$ per $\mathrm{kg}$ of soil.

\begin{tabular}{|c|c|c|c|c|c|c|c|c|c|c|c|}
\hline \multirow{3}{*}{$\begin{array}{c}\text { Annettu } \\
\text { Given } \\
\mathrm{CaCO}_{3} \\
\mathrm{~g} / 100 \mathrm{~g}\end{array}$} & \multirow{3}{*}{$\mathrm{pH}$} & \multirow{3}{*}{$\begin{array}{l}\mathrm{Hu}- \\
\text { mus- } \\
\%\end{array}$} & \multirow{3}{*}{$\begin{array}{c}\text { Koko- } \\
\text { nais- } \\
P \\
\text { Total- } \\
\text { P }\end{array}$} & \multicolumn{6}{|c|}{$\begin{array}{l}\text { NaOH-käsittelyssä liuennut } \mathrm{P} \\
\mathrm{P} \text { dissolved by NaOH-treatment }\end{array}$} & \multirow{3}{*}{\begin{tabular}{|c|} 
Laktaatti- \\
uutoksella \\
liuennut \\
Dissolved \\
withlactate \\
extract. \\
$\mathrm{mg} / \mathrm{kg}$ \\
\end{tabular}} & \multirow{3}{*}{$9+11$} \\
\hline & & & & \multicolumn{2}{|c|}{$\begin{array}{c}\text { Kaikkiaan } \\
\text { Total }\end{array}$} & \multicolumn{2}{|c|}{$\begin{array}{c}\text { Epäorgaanista } \\
\text { Inorganic }\end{array}$} & \multicolumn{2}{|c|}{$\begin{array}{c}\text { Edellisten ero }= \\
\text { orgaanista } \\
\text { Total minus inorga- } \\
\text { nic }=\text { organic }\end{array}$} & & \\
\hline & & & & $\mathrm{mg} / \mathrm{kg}$ & $\%$ & $\mathrm{mg} / \mathrm{kg}$ & $\%$ & $\mathrm{mg} / \mathrm{kg}$ & $\%$ & & \\
\hline 1 & 2 & 3 & 4 & $5 \mid$ & 6 & 7 & 8 & 9 & 10 & 11 & 12 \\
\hline \multicolumn{12}{|c|}{ Urpasavi 3, kyntömulta, Paimio. - Muddy clay 3, surface soil. } \\
\hline 1) & 4.83 & 5.95 & 1050 & 800 & 76 & 300 & 28 & 500 & 48 & 11 & 511 \\
\hline 0 & 4.43 & 5.70 & & 800 & 76 & 310 & 30 & 490 & 46 & 20 & 510 \\
\hline 1 & 6.70 & 5.55 & & 790 & 75 & 320 & 30 & 470 & 45 & 30 & 500 \\
\hline 2 & 7.14 & 5.18 & & 680 & 65 & 305 & 29 & 375 & 36 & 35 & 510 \\
\hline \multicolumn{12}{|c|}{ Urpasavi 4, pohjamaa, Paimio. - Muddy clay 4, subsoil. } \\
\hline 1) & 4.16 & & 750 & 470 & 63 & 385 & 52 & 85 & 11 & 0 & 85 \\
\hline 0 & 3.89 & 1.99 & & 490 & 65 & 375 & 50 & 115 & 15 & 0 & 115 \\
\hline 1 & 6.10 & 1.86 & & 450 & 60 & 345 & 46 & 105 & 14 & 0 & 105 \\
\hline 2 & 7.00 & 1.86 & & 430 & 57 & 325 & 43 & 105 & 14 & 2 & 107 \\
\hline \multicolumn{12}{|c|}{ Aitosavi 5, kyntömulta, Kilo. - Heavy clay 5, surface soil. } \\
\hline 1) & 5.60 & 5.44 & 1220 & 850 & 70 & 330 & 27 & 520 & 43 & 19 & 539 \\
\hline 0 & 5.00 & 5.55 & & 825 & 68 & 330 & 27 & 495 & 41 & 23 & 518 \\
\hline 1 & 6.64 & 5.50 & & 780 & 64 & 325 & 27 & 455 & 37 & 44 & 499 \\
\hline 2 & 6.97 & 5.36 & & 690 & 57 & 305 & 25 & 385 & 32 & 52 & 437 \\
\hline \multicolumn{12}{|c|}{ Aitosavi 6, pohjamaa, Kilo. - Heavy clay 6, subsoil. } \\
\hline 1) & 6.70 & 0.36 & 800 & 145 & 18 & 130 & 16 & 15 & 2 & 97 & 112 \\
\hline 0 & 6.26 & 0.55 & & 120 & 15 & 95 & 12 & 2.5 & 3 & 88 & 113 \\
\hline 1 & 7.17 & 0.52 & & 85 & 11 & 60 & 8 & 25 & 3 & 40 & 65 \\
\hline 2 & 7.34 & 0.52 & & 55 & 7 & 40 & 5 & 15 & 2 & 20 & 35 \\
\hline \multicolumn{12}{|c|}{ Hietasavi 7 , kyntömulta, Pälkäne. — Silt clay 7 , surface soil } \\
\hline 1) & 5.04 & 4.50 & 1200 & 790 & 66 & 410 & 34 & 380 & 32 & 14 & 394 \\
\hline 0 & 4.77 & & & 765 & 64 & 420 & 35 & 345 & 29 & 15 & 360 \\
\hline 0.5 & 6.05 & & & 750 & 62 & 400 & 33 & 350 & 29 & 22 & 372 \\
\hline 1 & 7.14 & & & 720 & 60 & 380 & 32 & 340 & 28 & 33 & 373 \\
\hline \multicolumn{12}{|c|}{ Vakkila A, kevyt savi, ei lannoitusta. - Light clay, no fertilizers. } \\
\hline 1) & 5.11 & & 1375 & 1000 & 73 & 490 & 36 & 510 & 37 & 11 & 521 \\
\hline 0 & 4.83 & 3.47 & & 880 & 64 & 465 & 34 & 415 & 30 & 19 & 434 \\
\hline 0.5 & 6.36 & 3.36 & & 840 & 61 & 460 & 33 & 380 & 28 & 31 & 411 \\
\hline 1 & 7.19 & 3.36 & & 820 & 60 & 440 & 32 & 380 & 28 & 50 & 430 \\
\hline \multicolumn{12}{|c|}{ Vakkila B, kevyt savi, karjalantaa 25 to/ha. — Light clay, 25 to/ha dung. } \\
\hline 1) & 5.21 & 4.60 & 1350 & 970 & 72 & 480 & 36 & 490 & 36 & 16 & 506 \\
\hline 0 & 4.94 & & & 900 & 67 & 480 & 36 & 420 & 31 & 27 & 447 \\
\hline 0.5 & 6.34 & & & 880 & 65 & 470 & 35 & 410 & 30 & 40 & 450 \\
\hline 1 & 7.07 & & & 860 & 64 & 460 & 34 & 400 & 30 & 58 & 458 \\
\hline
\end{tabular}

1) Alkuperäinen maa. - No incubation. 
(Taulukko $I$, jatkoa.)

\begin{tabular}{|c|c|c|c|c|c|c|c|c|c|c|c|}
\hline 1 & 2 & 3 & 4 & 5 & 6 & 7 & 8 & 9 & 10 & 11 & 12 \\
\hline Vakkila & C, kevyt & savi, 2 & o sup & $\begin{array}{r}f ., 300 \\
\text { sal }\end{array}$ & $\begin{array}{l}\text { alis. } \\
200\end{array}$ & $\begin{array}{l}200 \\
\text { trate }\end{array}$ & p. - & ht c & & \multicolumn{2}{|c|}{300 potash } \\
\hline 1) & 4.99 & \multirow[t]{4}{*}{5.13} & \multirow[t]{4}{*}{1425} & 1110 & 78 & 550 & 39 & 560 & 39 & 21 & 581 \\
\hline 0 & 4.68 & & & 1110 & 78 & 510 & 36 & 600 & 42 & 24 & 624 \\
\hline 0.5 & 5.88 & & & 1105 & 78 & 510 & 36 & 595 & 42 & 32 & 627 \\
\hline 1 & 6.70 & & & 1040 & 73 & 505 & 35 & 535 & 38 & 50 & 585 \\
\hline \multicolumn{12}{|c|}{ Kokemäki 0 , hieta, ei lannoitusta. - Silt, no fertilizers. } \\
\hline 1) & 5.44 & \multirow[t]{4}{*}{3.52} & \multirow[t]{4}{*}{1025} & $640^{\circ}$ & 63 & 210 & 21 & 430 & 42 & 7 & 437 \\
\hline 0 & 5.49 & & & 620 & 61 & 205 & 20 & 415 & 41 & 10 & 425 \\
\hline 0.5 & 6.86 & & & 600 & 59 & 205 & 20 & 395 & 39 & 23 & 418 \\
\hline 1 & 7.24 & & & 560 & 55 & 210 & 21 & 350 & 34 & 25 & 375 \\
\hline
\end{tabular}

Kokemäki 2PN, hieta, 400 superf., I00 amm. sulf. - Silt, 400 superph., 100 amm. sulphate.

\begin{tabular}{c|c|c|c|c|c|c|c|c|c|c|c|c|}
1 & 5.41 & 3.55 & 1125 & 770 & 69 & 280 & 25 & 490 & 44 & 18 & 508 \\
\hline 0 & 5.00 & & & 700 & 62 & 265 & 23 & 435 & 39 & 16 & 451 \\
0.5 & 6.71 & & & 690 & 61 & 240 & 21 & 450 & 40 & 25 & 475 \\
1 & 7.27 & & & 630 & 56 & 260 & 23 & 370 & 33 & 34 & 404
\end{tabular}

Myttäälä 0, hiekka, ei lannoitusta. - Sand, no fertilizers.

\begin{tabular}{|c|c|c|c|c|c|c|c|c|c|c|c|}
\hline 1) & 4.90 & 3.47 & 550 & 345 & 63 & 155 & 28 & 190 & 35 & 5 & 195 \\
\hline 0 & 4.67 & & & 243 & 44 & 150 & 27 & 93 & 17 & 5 & 98 \\
\hline 0.4 & 5.97 & & & 220 & 40 & 148 & 27 & 72 & 13 & 9 & 81 \\
\hline 1 & 7.17 & & & 185 & 34 & 135 & 25 & 50 & 9 & 12 & 62 \\
\hline
\end{tabular}

Myttäää 2PK, hiekka, 430 superf., I60 kalis. - Sand, 430 superph., 160 potash salt.

\begin{tabular}{|c|c|c|c|c|c|c|c|c|c|c|c|c|}
$1)$ & 4.82 & & 625 & 445 & 71 & 225 & 36 & 220 & 35 & 13 & 243 \\
0 & 4.67 & 4.40 & & 370 & 59 & 215 & 34 & 155 & 25 & 14 & 269 \\
0.4 & 6.05 & 4.15 & & 360 & 58 & 210 & 34 & 150 & 24 & 44 & 294 \\
1 & 7.30 & 4.25 & & 320 & 51 & 200 & 32 & 120 & 19 & 35 & 155
\end{tabular}

Myttäälä 4 PK, hiekka, 860 superf., I6o kalis. - Sand, 860 superph., 610 potash salt.

\begin{tabular}{|c|c|c|c|c|c|c|c|c|c|c|c|c|}
\hline 1$)$ & 4.87 & 4.50 & 600 & 420 & 70 & 240 & 40 & 180 & 30 & 25 & 205 \\
0 & 4.73 & & & 380 & 63 & 220 & 37 & 160 & 26 & 27 & 187 \\
\hline 0.4 & 5.85 & & & 360 & 60 & 250 & 42 & 110 & 18 & 33 & 143 \\
\hline 1 & 7.20 & & & 350 & 58 & 255 & 42 & 95 & 16 & 58 & 153 \\
\hline
\end{tabular}

Myttäää ${ }_{4} P K_{4} N$, hiekka, 860 superf., I60 kalis., 600 salp. - Sand, 860 superph., 160 potash salt, 600 nitrate of chalk.

\begin{tabular}{|c|c|c|c|c|c|c|c|c|c|c|c|}
\hline 1 & 5.00 & 4.66 & 525 & - & - & - & - & - & - & 19 & - \\
\hline 0 & 4.87 & & & 410 & 78 & 230 & 44 & 180 & 34 & 30 & 210 \\
0.4 & 6.22 & & & 390 & 74 & 235 & 45 & 155 & 29 & 39 & 194 \\
1 & 7.20 & & & 350 & 67 & 220 & 42 & 130 & 25 & 58 & 188
\end{tabular}

Myttäälä PK, hiekka, 215 superf., I6o kalis. - Sand, 215 superph., 160 potash salt.

\begin{tabular}{c|c|c|c|c|c|c|c|c|c|c|c|}
11 & 4.90 & 4.35 & 425 & - & - & - & - & - & - & 8 & - \\
0 & 4.77 & & & 275 & 65 & 125 & 30 & 150 & 35 & 11 & 161 \\
0.4 & 6.02 & & & 270 & 63 & 120 & 28 & 150 & 35 & 13 & 163 \\
1 & 7.10 & & & 240 & 56 & 120 & 28 & 120 & 28 & 19 & 139
\end{tabular}


tapauksissa hyvinkin paljon. Epävarma ja joka tapauksessa sangen pieni on laktaattiin liukenevan fosforin lisääntyminen urpasavi 4:ssä. Aitosavi 6:ssa, jossa laktaattiin liukenevaa fosforia on erittäin paljon, kalkituksen vaikutus on ollut suorastaan negatiivinen.

Käsityksen saamiseksi siitä, lisääntyykö laktaattiin liukeneva fosfori samassa suhteessa kuin orgaaninen vähenee, on taulukon 1 viimeiseen sarakkeeseen laskettu orgaanisen fosforin ja laktaattiin liukenevan summat. Tällaisesta laskelmasta ei voi odottaakaan mitään tasaisia lukuja, mutta kuitenkin niistä voi nähdä, että nämä summat pysyvät jokseenkin samoina eri suurilla kalkituksilla. Orgaanisesta aineesta vapautuva fosfori näyttää siis muuttuvan laktaattiin liukenevaksi.

\section{Kalkitus ja "jumriliukoinen" fosfori.}

Neubauerin mukaan tehtäviä orasanalyysejä varten kalkittiin ja pantiin muhimaan muutamia suurempia maanäytteitä, $250 \mathrm{~g}$ kuiva-ainetta. Menettelytapa niissä oli aivan sama kuin edellä selostetuissa mobilisaatiokokeissakin. Siinä käytettiin myös samoja maanäytteitä, jotka tässä merkitään samalla tavalla. Niissä käytettiin vain yhtä kalkitusta, $1 \mathrm{~g} \mathrm{CaCO} / 100 \mathrm{~g}$ mata. Vaikutusaika oli $6 \mathrm{kk}$, minkä jälkeen maat kuivattiin ja homogenisoitiin. Orasanalyysit tehtiin seuraten Neubauerin (5) ohjeita. Kun rukiinoraat tällä tapaa kerran kasvatettuina eivät yleensä ota kaikkea juuriliukoista fosforia, halusin tehdä useita peräkkäisiä orasanalyysejä samoista maista. Siinä käytin SchAchtschABELin (7) esittämää menettelyä, jossa kasvatuksen jälkeen maaerä juurineen kuivataan sopivasti ja hieromalla poistetaan enin multa juurista ja lopuksi pestään vähällä vedellä, joka otetaan talteen ja haihdutetaan kuiviin, jolloin se voidaan taas yhdistää muuhun maahan.

Humusköyhissä pohjamaanäytteissä oli suuri vaara tarjolla, että maata kostutettaessa se liettyy ja tiivistyy niin pahasti, että juurien kasvu vaikeutuu. Osoittautui, että tavallisella kostutusmenetelmällä maan liettyminen ei ollut vältettävissä. Vaikeuden ratkaisin siten, että kostutin maan aluksi vain 2/3:1la tarvittavasta vesimäärästä. Tämä ei vielä lietä maata. Maa sekoitettiin tämän jälkeen ja tasoitettiin suurella kumitulpalla varovasti. Puuttuva vesimäärä annettiin peitehiekkaan, josta se imeytyi allạolevaan maahan liettämättä sitä.

Ettei pohjamaanäytteissä typen puute olisi haitannut oraiden kasvua, annettiin niihin $5 \mathrm{mg}$ $\mathrm{N} \mathrm{NH} \mathrm{NO}_{3}$ :ssa.

Kun orasanalyysejä tehdään peräkkäin useita samassa maaerässä, täytyy käyttää myös samaa peitehiekkaa eri kasvatuksissa, sillä huolellisellakaan menettelyllä ei voida kokonaan välttää sitä, että văhän maata sekaantuu hiekkaan. Hiekka saastuu homeella, joka pahasti häiritsee myöhempiä kasvatuksia. Homeen lisääntymisen estin siten, että astioiden tyhjentämisen jälkeen kostutin peitehiekan 50 ml:lla $0.5 \%$ :ista formaliinia, joka sitten sai haihtua. Näin menetellen ei myöhempiinkään kasvatuksiin ilmestynyt hometta, enkä huomannut, että oraiden kehityksessä olisi ilmennyt mitään häiriöitä. Formaliini ilmeisesti haihtuu riittävän tarkoin. SснAснтschabelin mainitsemaa ruskeiden läikkien ilmestymistä juuristoon ei esiintynyt.

Peräkkäin tehdyistä orasanalyyseistä sain taulukossa 2 esitetyt määrät fosforia. Luvut ovat keskiarvoja kahdesta rinnakkaismäärityksestä.

Orasanalyyseissä saadut tulokset käyvät samaan suuntaan kuin laktaattiuutoksella saadut luvut, lukuunottamatta sitä, että urpasavi 4:stä on saatu oras- 
Taulukko 2. Kalkituksen vaikutus juuriliukoisen fosforin määriin $m g$ P/IOo g maata.

Table 2. The effect of liming on the quantities of root-soluble phisphorus $\mathrm{P} \mathrm{mg} / 100 \mathrm{~g}$ soil,

\begin{tabular}{|c|c|c|c|c|}
\hline \multirow[t]{2}{*}{$\cdot$} & \multirow[t]{2}{*}{$\begin{array}{c}\text { Kalkittu } \\
\text { Limed }\end{array}$} & \multirow{2}{*}{$\begin{array}{c}\text { Ilman kalkkia } \\
\text { Unlimed }\end{array}$} & \multicolumn{2}{|c|}{$\begin{array}{c}\text { Kalkituksella saatu } \\
\text { lisäys - Addition } \\
\text { gained by liming }\end{array}$} \\
\hline & & & $\mathrm{mg} \mathrm{P}$ & $\%$ \\
\hline $\begin{array}{l}\quad \text { Urpasavi } 3 .- \text { Muddy clay } 3 . \\
\text { I. kasvatus }-1 \text {. harvest } \ldots \ldots \ldots \ldots \\
\text { 2. kasvatus }- \text { 2. harvest } \ldots \ldots \ldots \ldots \\
\text { 3. kasvatus }- \text { 3. harvest } \ldots \ldots \ldots \ldots\end{array}$ & $\begin{array}{l}1.63 \\
1.13 \\
0.77\end{array}$ & $\begin{array}{r}0.75 \\
0.55 \\
-0.39 \\
\end{array}$ & $\begin{array}{l}0.88 \\
0.58 \\
1.16\end{array}$ & \\
\hline $\begin{array}{l}\text { Yhteensä - Total } \\
\text { Urpasavi 4. - Muddy clay } 4 . \\
\text { I. kasvatus }- \text { 1. harvest } \ldots \ldots \ldots \ldots \\
\text { 2. kasvatus }- \text { 2. harvest } \ldots \ldots \ldots \ldots \\
\text { 3. kasvatus }- \text { 3. harvest } \ldots \ldots \ldots \ldots\end{array}$ & $\begin{array}{l}0.45 \\
0.40 \\
0.87\end{array}$ & $\begin{array}{l}0.27 \\
0.45 \\
0.41\end{array}$ & $\begin{array}{r}0.18 \\
-0.05 \\
0.46\end{array}$ & 288 \\
\hline $\begin{array}{l}\text { Yhteensä - Total } \\
\qquad \text { Aitosavi 5. - Heavy clay } 5 . \\
\text { I. kasvatus - 1. harvest } \ldots \ldots \ldots \ldots \\
\text { 2. kasvatus - 2. harvest } \ldots \ldots \ldots \ldots \ldots \\
\text { 3. kasvatus - 3. harvest } \ldots \ldots \ldots \ldots \\
\end{array}$ & $\begin{array}{l}2.45 \\
1.78 \\
1.33 \\
\end{array}$ & $\begin{array}{l}1.50 \\
0.44 \\
0.57 \\
\end{array}$ & $\begin{array}{l}0.95 \\
1.34 \\
0.76 \\
\end{array}$ & 52 \\
\hline $\begin{array}{l}\qquad \text { Yhteensä }- \text { Total } \\
\qquad \text { Aitosavi 6. - Heavy clay } 6 . \\
\text { I. kasvatus }- \text { 1. harvest } \ldots \ldots \ldots \ldots \\
\text { 2. kasvatus }- \text { 2. harvest } \ldots \ldots \ldots \ldots \\
\text { 3. kasvatus }- \text { 3. harvest } \ldots \ldots \ldots \ldots\end{array}$ & $\begin{array}{l}0.66 \\
0.35 \\
0.38 \\
\end{array}$ & $\begin{array}{l}1.13 \\
1.48 \\
2.38 \\
\end{array}$ & $\begin{array}{r}3.05 \\
-0.47 \\
-1.13 \\
-2.00 \\
\end{array}$ & 121 \\
\hline Yhteensä - Total & 1.39 & 4.99 & -3.60 & -72 \\
\hline
\end{tabular}

analyysissä pieni määrä fosforia, kun laktaattiuutoksella on saatu vastaavalla kalkituksella selvä nolla. Tämän mukaan siis urpasavessa vallitsevat ferri- ja aluminiumfosfaatit ovat kasveille käyttökelpoisempia kuin laktaattiuutos osoittaa. Kalkituksen negatiivinen vaikutus aitosavi 6:ssa, pohjamaa, ilmenee orasanalyysissä hyvin selvänä. Sama ilmiö, joka tuli näkyviin laktaattiuutoksessa. Laktaattiuutos antoi kalkitsemattomasta aitosaven pohjamaasta n:o 6 hyvin korkeita lukuja. Orasanalyysi osoittaa, ettei tämä helppoliukoinen fosfori kuitenkaan ole läheskään kokonaisuudessaan kasvien käytettävissä.

Orasanalyysilukuja tarkasteltaessa huomataan, että toisella ja kolmannellakin kasvatuskerralla on vielä saatu juuriliukoista fosforia kalkitsematonta urpasavi 3:a lukuunottamatta. Urpasavi 4:stä ja aitosavi 6:sta kalkitsemattomana on kolmannella kasvatuksella saatu jopa enemmän kuin ensimmäisellä. Todennäköisesti olisi jatketuilla oraiden kasvattamisilla saatu vieläkin juuriliukoista fosforia, mutta kasvatuksia ei ollut tilaisuutta jatkaa. Voidaan päätellä, että maassa ei ole mitään selvästi rajoitettua fraktiota fosforihappoa, joka olisi kasvien käytettävissä, vaan sitä mobilisoituu vähitellen. 


\section{Tulosten tarkastelua.}

Jos esilläolevassa tutkimuksessa olisi ollut käytettävissä sellaisia maanäytteitä, joissa toisissa olisi ollut orgaanista fosforia, mutta ei lainkaan ferri- ja aluminiumfosfaatteja, ja toisissa taas päinvastoin vain ferri- ja aluminiumfosfaatteja, mutta ei orgaanista fosforia, olisi esitetyn tapaisissa kokeissa voitu saada selvä käsitys kumpaisienkin suhtautumisesta kalkitukseen. Tällaisia maanäytteitä tuskin kuitenkaan on saatavissa, sillä elomultakerros, jossa orgaanista fosforia etupäässä on, on aina jonkin verran huuhtoutunut ja sisältää silloin myös ferri- ja aluminiumfosfaatteja, ja toiselta puolen urpamaa, jossa ferri- ja aluminiumfosfaatit ovat vallitsevia, sisältää myös aina eloperäistä ainetta ja siis myös orgaanista fosforja. Keinotekoisista aineista ja keinotekoisesti muutetuista maista taas on pelättävissä, että niissä fosforinkin suhtautuminen on luonnollisesta maasta poikkeavaa. Tässä tutkimuksessa on tahdottu selvittää ilmiötä olosuhteissa, jotka mahdollisimman suuressa määrässä muistuttavat luonnossa ja käytännöllisessä kasvinviljelyksessä vallitsevia.

Maan kalkkipitoisuudella on suuri vaikutus fosforin esiintymismuotoihin sinä. Senvuoksi tehtiin orasanalyyseihin käytetyistä maista myös vaihtuvan kalkin määritykset Tuorilan (10) esittämällä tavalla ${ }^{1}$. Niistä saatiin seuraavat tulokset:

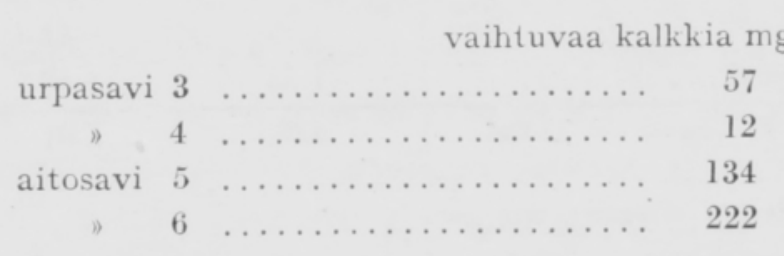

Aitosavi 5:ssä ọ vähemmän vaihtuvaa kalkkia kuin aitosavi 6:ssa. Se on kyntömultana jonkinverran huuhtoutunut, ja samalla on osa sen fosfaateista muuttunut ferri- ja aluminiumfosfaaterksi. Tämä nähdään emäkseen liukenevan epäorgaanisen fosforin määristä (taulukko 1). Kuitenkin on aitosavi 5:ssä paljon enemmän vaihtuvaa kalkkia kuin urpasavissa, joten se on siinä suhteessa verrattavissa aitosavi 6:een. Näillä samoilla maanäytteillä tehdyssä aikaisemmassa tutkimuksessa (6) on ilmennyt, että fosforin suhtautuminen on aitosavissa keskenään jokseenkin samanlaista ja poikkeavaa urpasavien fosforin suhtautumisesta, joissa se taas on keskenään samantapaista.

Vaikka tutkimukseen käytettyjen maanäytteiden valinnassa ei olekaan onnistuttu saamaan tässä asetetun kysymyksen ratkaisemiseksi ihanteellisia tapauksia, voidaan saatujen tuloksien perusteella silti tehdä melkoisella varmuudella muutamia johtopäätöksiä.

\section{Päätelmät.}

Saatujen tulosten perusteella voidaan päätellä, että kalkituksen johdosta tapahtuvassa helppoliukoisen ja kasveille käyttökelpoisen fosforin lisääntymisessä on orgaanisen fosforin mobilisoitumisella suuri osuus, sillä helppoliukoisen ja kas-

1) Vaihtuvan kalkin mäaritykset on tehty Valtion maanviljelyskemiallisessa laboratoriossa. 
veille käyttökelpoisen fosforin lisääntyminen on suurinta maissa, joissa on runsaasti orgaanista fosforia. Ilmeisesti myös ferri- ja aluminiumfosfaattien hydrolysoitumisella on osuutensa tässä ilmiössä, sillä maassa, jossa on vähän orgaanista fosforia, mutta runsaasti ferri- ja aluminiumfosfaatteja, tapahtuu kalkituksen johdosta selvää, joskin melko vähäistä kasveille käyttökelpoisen fosforin lisääntymistä, jota ei tapahdu maassa, missä ei ole orgaanista fosforia eikä ferri- ja aluminiumfosfaatteja.

Lannoitus ei näytä vaikuttavan orgaanisen fosforin suhteellisiin määriin, vaan se näyttää lisäävän niitä samassa suhteessa kuin totalifosforiakin. Maan orgaanisen fosforin suhteellinen määrä näyttää riippuvan enemmän maalajista, kuin käytetystä lannoituksesta.

\section{KIRJALLISUUTTA:}

(1) Alten, F., B. Wandrowsky und E. Knippenberg, Beitrag zur Humusbestimmung. Ergebnisse der Agrikulturchemie 4, s. 61-69, 1935.

(2) Egner, H., G. Köhler und F. Nydahl, Die Laktatmethode zur Bestimmung leichtlöslicher Phosphorsäure in Ackerböden. Lantbrukshögskolans Annaler 6, s. 253-298, 1938.

(3) GaArder, T., Die Bindung der Phosphorsäure im Erdboden. Medd. fra Vestlandets forstl. forsøkstation 14, 1930 .

(4) Mattson, S. and N. Karlsson, The electro-chemistry of soil formation II. The phosphate complex. Lantbrukshögskolans Annaler 6, s. 109-157, 1938.

(5) Neubauer, H., Die Keimpflanzenmethode. Berlin 1939.

(6) Salonen, M., Fosforin esiintymismuodoista Suomen maalajeissa. Acta Agralia Fennica 48, 1941.

(7) Schachtschabel, P., Aufnahme von nicht-austaschbaren Kali durch die Pflanzen. Bodenkunde und Pflanzenernährung 3 , s. 107-133, 1937.

(8) Semb, G., Undersøkelser over Fosforsyrens oppløselighet og binding i Østnorske jordtyper. Meldinger fra Norges Landbrukshøgskole, s. 1-145, 1943.

(9) Torstensson, G. und S. ERtksson, Ein Beitrag zur Frage der Ausnutzung der Düngerphosphorsäure in sauren Böden. Lantbrukshögskolans Annaler 11, s. 82-106, 1943.

(10) TUORILA, P., Några problem rörande kalkningsfrågan. Svenska Vall- och Mosskulturföreningens Kvartalskrift 7, s. 83-101, 1945. 


\title{
SUMMARY.
}

\section{EFFECT OF LIMING ON ORGANIC AND EASILY SOLUBLE PHOSPHORUS OF SOIL.}

\author{
Martit Salonen. \\ Institute of Agricultural Chemistry, University of Helsinki.
}

The purpose of the investigation is to elucidate which part of the phosphorus of soil is changed to easily soluble and root-soluble by liming and how fertilizing effects on the organic phosphorus of soil.

For test material samples were selected to represent as far as possible the types of soil in which 1 . the total phosphorus consists to a great extent of organic phosphorus and to a smallest possible extent of ferric and aluminium phosphates (heavy clay 5) and 2 . the total phosphorus consists to a great extent of ferric and aluminium phosphates and to a small extent of organic phosphorus (muddy clay 4). Besides, in some samples phosphorus is present both in organic form and as ferric and aluminium phosphates (muddy clay 3 ), and the content of both being low (heavy clay 6 ). In addition, samples have been obtained from many years' fertilizer experiment fields.

Soil samples have been preserved limed and moistened in different ways for 9 months (Table 1) and for 6 months (Table 2). After incubation time the organic phosphorus of samples was determined by treating with $0.25 \mathrm{~N} \mathrm{NaOH}$ and easily soluble phosphorus with lactate method (Table 1). The samples preserved for a shorter period were analyzed according to NEUBAUER test whereby 3 successive harvests were made (Table 2).

Due to liming organic phosphorus was decreased and the lactate-soluble phosphorus increased in samples containing amply organic phoshorus (Table 1). The Neubauer test gave similar results as the lactate method (Table 2).

It can be concluded from the data that the increase of lactate-soluble and root-soluble phosphorus caused by liming is to a large extent ascribable to mobilization of organic phosphorus since it is greatest in soils where the percentage of organic phosphorus is highest. A part of the increase of easily soluble phosphorus is due to hydrolyzation of ferric and aluminium phosphates, since also in samples, containing little organic phosphorus but plenty of ferric and aluminium phosphates (muddy clay 4), increase of easily soluble phosphorus has occurred. In soil containing very little phosphorus both in organic form and as ferric and aluminium phosphates no increase of easily soluble phosphorus has been noted, on the contrary, a distinct reduction has been observed.

Fertilizing has no effect on the percentage of organic phosphorus (Table 1). It seems that the amount of organic phosphorus depends more on the type of soil than on fertilizing. 